Article

\title{
Jasmonic Acid Effect on the Fatty Acid and Terpenoid Indole Alkaloid Accumulation in Cell Suspension Cultures of Catharanthus roseus
}

\section{Guitele Dalia Goldhaber-Pasillas *, Natali Rianika Mustafa and Robert Verpoorte}

Natural Products Laboratory, Institute of Biology Leiden, Leiden University, Sylvius Laboratoria, Sylviusweg 72, 2300 RA, Leiden, The Netherlands

* Author to whom correspondence should be addressed; E-Mail: daliagoldhaber@gmail.com; Tel.: +31-0-71-5274-528; Fax: +31-0-71-5274-511.

Received: 4 May 2014; in revised form: 23 June 2014 / Accepted: 10 July 2014 /

Published: 15 July 2014

\begin{abstract}
The stress response after jasmonic acid (JA) treatment was studied in cell suspension cultures of Catharanthus roseus. The effect of JA on the primary and secondary metabolism was based on changes in profiles of fatty acids (FA) and terpenoid indole alkaloids (TIA). According to multivariate data analyses (MVDA), three major time events were observed and characterized according to the variations of specific FA and TIA: after 0-30 min of induction FA such as C18:1, C20:0, C22:0 and C24:0 were highly induced by JA; 90-360 min after treatment was characterized by variations of C14:0 and C15:0; and 1440 min after induction JA had the largest effect on both group of metabolites were C18:1, C18:2, C18:3, C16:0, C20:0, C22:0, C24:0, catharanthine, tabersonine-like 1, serpentine, tabersonine and ajmalicine-like had the most significant variations. These results unambiguously demonstrate the profound effect of JA particularly on the accumulation of its own precursor, C18:3 and the accumulation of TIA, which can be considered as late stress response events to JA since they occurred only after $1440 \mathrm{~min}$. These observations show that the early events in the JA response do not involve the de novo biosynthesis of neither its own precursor nor TIA, but is due to an already present biochemical system.
\end{abstract}

Keywords: fatty acids; terpenoid indole alkaloids; Madagascar periwinkle; cell suspension cultures; jasmonic acid; multivariate data analysis 


\section{Introduction}

Fatty acids (FAs) are the most abundant form of reduced carbon chains available from nature and plant FAs represent a large reservoir of diversity with at least 200 different types that occur mainly in plants. In eukaryotic organisms like plants, they consist almost exclusively of 16 and 18-carbon FAs, being palmitic acid (C16:0) the major saturated FA followed by the unsaturated linolenic (C18:3), linoleic (C18:2) and oleic (C18:1) and these are often referred to as the common FAs [1] (Table 1).

Table 1. Common fatty acids with their chemical formula, common names and abbreviations.

\begin{tabular}{ccc}
\hline Systematic Name & Common Name & Formula \\
\hline Decanoic acid & Capric acid & $\mathrm{C} 10: 0$ \\
Dodecanoic acid & Lauric acid & $\mathrm{C} 12: 0$ \\
Tetradecanoic acid & Myristic acid & $\mathrm{C} 14: 0$ \\
$\Delta-9-$ Tetradecanoic acid & Myristoleic acid & $\mathrm{C} 14: 1$ \\
Pentadecanoic acid & Pentadecanoic acid & $\mathrm{C} 15: 0$ \\
Hexadecanoic acid & Palmitic acid & $\mathrm{C} 16: 0$ \\
$\Delta-9-$ Hexadecanoic acid & Palmitoleic acid & $\mathrm{C} 16: 1$ \\
Heptadecanoic acid & Heptadecanoic acid & $\mathrm{C} 17: 0$ \\
Octadecanoic acid & Stearic acid & $\mathrm{C} 18: 0$ \\
$\Delta-9-$ Octadecanoic acid & Oleic acid & $\mathrm{C} 18: 1 \mathrm{n} 9 \mathrm{c}$ \\
$\Delta-9,12-$-Octadecadienoic acid & Linoleic acid & $\mathrm{C} 18: 2$ \\
$\Delta-9,12,15-$ Octadecatrienoic acid & $\alpha-$ Linolenic acid & $\mathrm{C} 18: 3 \mathrm{n} 3$ \\
Eicosanoic acid & Arachidic acid & $\mathrm{C} 20: 0$ \\
Heneicosanoic acid & Heneicosanoic acid & $\mathrm{C} 21: 0$ \\
Docosanoic acid & Behenic acid & $\mathrm{C} 22: 0$ \\
Tetracosanoic acid & Lignoceric acid & $\mathrm{C} 24: 0$ \\
\hline
\end{tabular}

Fatty acids are essential molecules present in all living organisms. They serve as major source of reserve energy by being part of complex lipids and are essential components of cellular membranes [2]. Moreover, they are also key molecules that participate in various biological processes [3]. In plants, composition and turnover of intracellular lipids and FAs are frequently altered during development and are among the first targets of environmental cues [4]. For example, the polyunsaturation of FAs has proven to be correlated to adaptation when plants are challenged with high or low temperatures $[5,6]$ or high salinity [7] and consequently they modulate a variety of responses to biotic and abiotic stresses.

One of the best-characterized FA-derived signal molecules is jasmonic acid (JA) along with its derivatives, collectively known as oxylipins or jasmonates (JAs). They play a role of master switch in many plant responses to biotic and abiotic factors such as wound response after herbivore attack, ultraviolet light or ozone, drought, but they also modulate flower, seed and fruit development, seed germination, pollen viability, anthocyanin accumulation, fruit ripening [8], tuberization in Solanum, tendril coiling in Bryonia and promotion of leaf senescence [9-11]. Jasmonic acid and its methyl ester (MeJA) have also a positive effect on the signal transduction chain leading to the accumulation of highly valued terpenoid indole alkaloids (TIA) in C. roseus. Both JAs induce most of the known TIA pathway genes [12], which results in higher levels of TIA in cell suspensions of C. roseus [13]. 
The coordinated expression of biosynthetic genes is mediated through the octadecanoid-responsive Catharanthus AP2-domain proteins ORCA2 and ORCA3, which are both induced by JA [14,15].

The accumulation of TIA can be considered as a late response in the jasmonate-mediated stress response in $C$. roseus where the expression of biosynthetic genes such as geraniol 10-hydroxylase $(G 10 H)$, tryptophan decarboxylase (TDC), strictosidine synthase (STR) and strictosidine $\beta$-D-glucosidase $(S G D)$ (Scheme 1) takes place after $2 \mathrm{~h}$ of induction [12,16] and the accumulation of TIA are detected in significant amounts only after $4-24 \mathrm{~h}$ of induction $[17,18]$. Therefore, since the rapid burst of jasmonates after wounding and feeding with JA takes place within $30 \mathrm{~s}$ [19], it is considered as an early response that precedes any transcriptional activity. Further events that involve the de novo biosynthesis of precursors, the de novo production of enzymes or secondary metabolites is considered as a late event in the JA-mediated stress response. As a part of an integrative study on the fast jasmonate response, we attempted to contribute to the knowledge on FA and TIA accumulation after treating cell suspensions of $C$. roseus with JA to establish a time frame where all these responses occur both in primary and secondary metabolism.

Scheme 1. Biosynthetic pathway of TIA in C. roseus (modified from [20]). Broken arrows indicate multiple enzymatic reactions. Enzymes with their corresponding cloned gene are indicated. Genes previously reported to be regulated by ORCA3 are indicated in gray boxes.

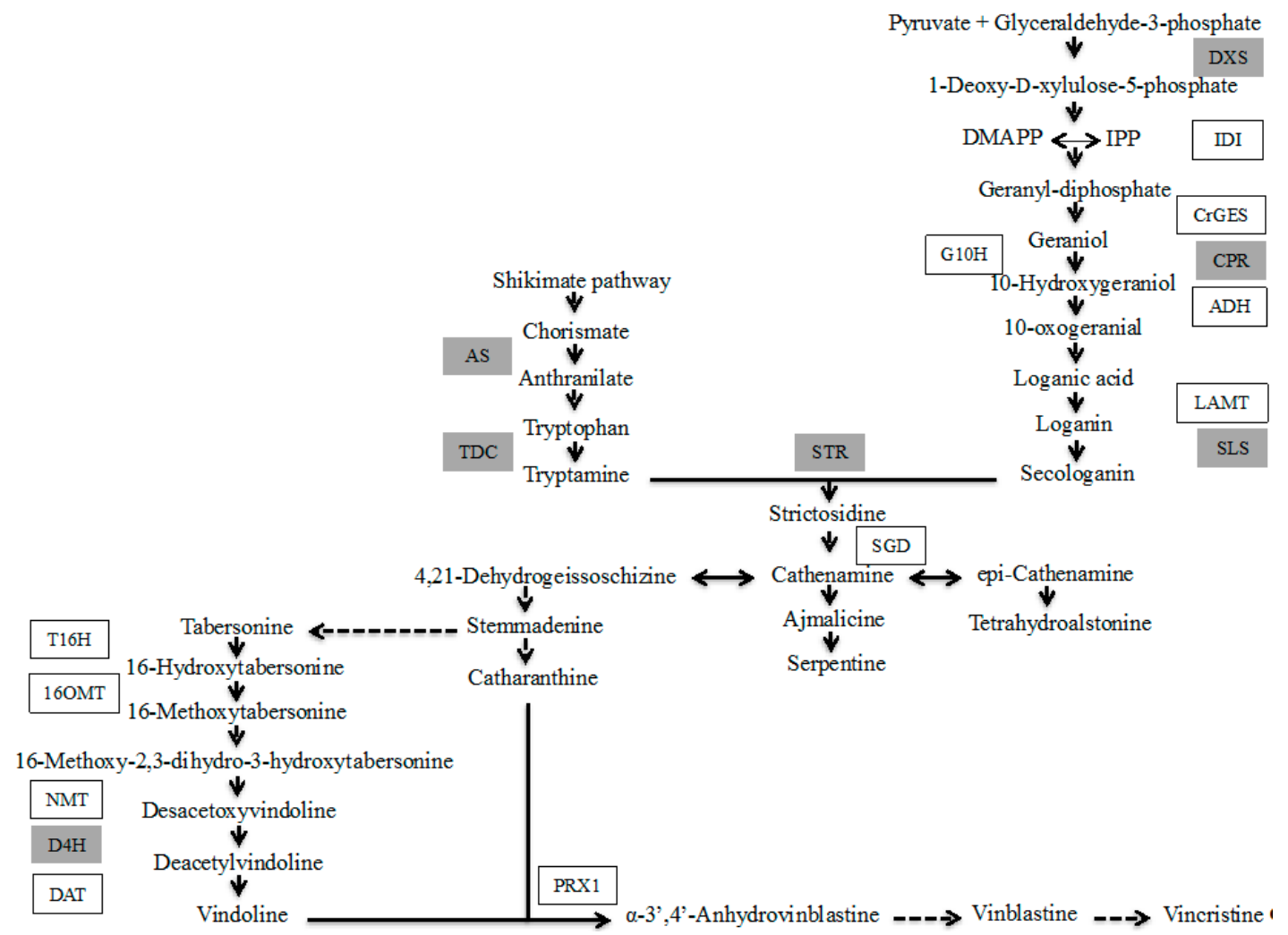

ADH: acyclic monoterpene primary alcohol dehydrogenase; AS: anthranilate synthase; CPR: cytochrome P450 reductase; D4H: desacetoxyvindoline 4-hydrolase; DAT: acetyl-CoA:4-O-deacetylvindoline 4-Oacetyltransferase; DXS: 1-deoxy-D-xylulose-5-phosphate synthase; G10H: geraniol 10-hydroxylase; CrGES: geraniol synthase; IDI: isopentenyl diphosphate isomerase; LAMT: $S$-adenosyl-L-methionine:loganic acid methyltransferase; NMT: 16-methoxy-2,3-dihydro-3-hydroxytabersonine; 16OMT: 16-hydroxytabersonine16-O-methyltransferase; PRX1: peroxidase 1; SGD: strictosidine $\beta$-D-glucosidase; SLS: secologanin synthase; STR: strictosidine synthase; TDC: tryptophan decarboxylase; T16H: tabersonine 16-hydroxylase. 


\section{Results and Discussion}

\subsection{JA Induces the Biosynthesis of Its Own Precursor, C18:3}

The most abundant FAs present in suspension cultures of $C$. roseus were C16:0, C18:2 and C18:3 as previously reported in cell systems of $C$. roseus [6,8,21-25] whereas C10:0, C15:0, C21:0 and $\mathrm{C} 24: 0$ were detected as traces. Even-numbered species were predominant over the odd-numbered ones e.g., C9:0, C11:0, C13:0 and C15:0 [26-28]. Very long chain FAs such as C20:0, with a high predominance of even-numbered series, are compounds that rarely occur in suspension cultures, since they are mainly found in waxy surfaces as well as in seed oils [29]. Nevertheless, polyunsaturated FAs with chain lengths up to $\mathrm{C} 24: 0$ have been reported for calli and cell suspension cultures of different plant species [24,30-33].

According to the principal component analysis (PCA) scores plot of PC1 vs. PC2 (Figure 1A), a clear separation was achieved by PCA score plot where two main groups were observed: 0-5-30 min and 90-360-1440 min after elicitation. Examination of PCA loading plot of JA-treated cells showed that $\mathrm{C} 16: 0, \mathrm{C} 20: 0, \mathrm{C} 18: 3, \mathrm{C} 18: 2, \mathrm{C} 22: 0$ and $\mathrm{C} 18: 1$ and $\mathrm{C} 24: 0$ (Figure 1B) were the most influential FA for the separation with the highest variation in the model.

These observations suggest that JA is able to induce the biosynthesis of its own precursor, that is C18:3, but only at later time points i.e., $1440 \mathrm{~min}$ after induction which also means that changes in the FA composition of the membrane are not involved in the fast response after induction with JA.

A variation in FA profile after JA-elicitation suggests a remodeling in the lipid architecture of the membrane where the cell has to cope first with non-physiological amounts of JA with an efficient and fast mechanism of signal attenuation mainly accomplished by hydroxylation [34], epimerization or methyl esterification [35]. In wound-induced tissues, further responses involve the release of precursors from the membrane mediated by lipases to generate the substrates for JA synthesis as occurred for wound-induced leaves of tomato, where 15-fold increase of levels of C18:3 peaked $1 \mathrm{~h}$ after wounding, which correlated with an increase in JA [36,37]. These results differ from ours, where levels of $\mathrm{C} 18: 3$ had significant variations after $1440 \mathrm{~min}$ of treatment suggesting that at least in C. roseus, the JA-mediated response does not involve the relocation of precursors like C18:3 but the induction of the stress response pathway as it has been demonstrated in previous experiments where the exogenous application of $\mathrm{C} 18: 2$ and $\mathrm{C} 18: 3$ as elicitors, leads to the enhanced accumulation of secondary metabolites in root cultures of Panax ginseng [38,39], cell suspension cultures of Lycopersicon esculentum, Tinospora cordifolia, Erythrina cristagalli and Eschscholtzia californica [40] and LOX activity in N. tabacum cell cultures after 1-2 h of induction [41] suggesting the de novo biosynthesis of precursors.

Further analysis of the influence of JA on the FA profile in cells of C. roseus was observed by Partial least squares-discriminant analysis (PLS-DA) of the scores and loadings plots of treated cells showing a clustering of two main groups: 0-5-30 min and 90-360-1440 min (Figure 2). The scores (Figure 2A) and loadings (Figure 2B) plots examination of the first group revealed that JA had a marked influence on few FA such as C18:1, C18:3, C20:0 and C24:0 after 30 min of induction whereas the second group (Figure $2 \mathrm{C}, \mathrm{D}$ ) had the most prominent variations in a larger group with similar responses to JA i.e., C16:0, C18:3, C10:0, C18:1, C22:0, C24:0, C22:0 and C12:0. 
Figure 1. Multivariate data analysis of cell suspensions of $C$. roseus treated with JA. (A) PCA scores plot generated from PCA using GC-MS normalized data (PC1 vs. PC2) of treated cells and controls. The variances accounted by $\mathrm{PC} 1$ and $\mathrm{PC} 2$ were $57.1 \%$ and 17.2\%, respectively. (B) PCA loading plot from PCA (PC1 vs. PC2) showing the most influential FA. Black circles: JA-treated cells; white circles: untreated cells; grey circles: mock (40\% EtOH).

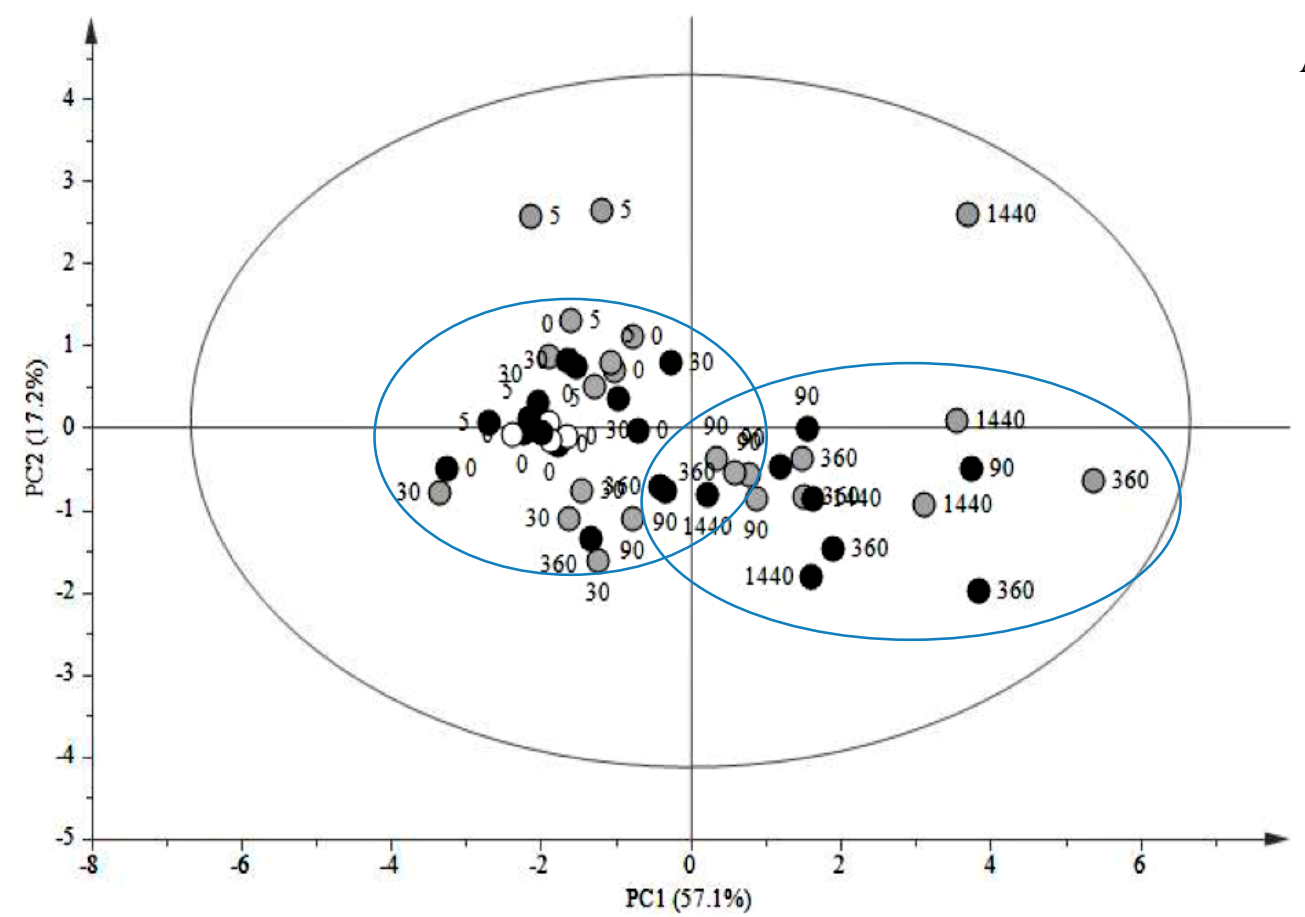

A

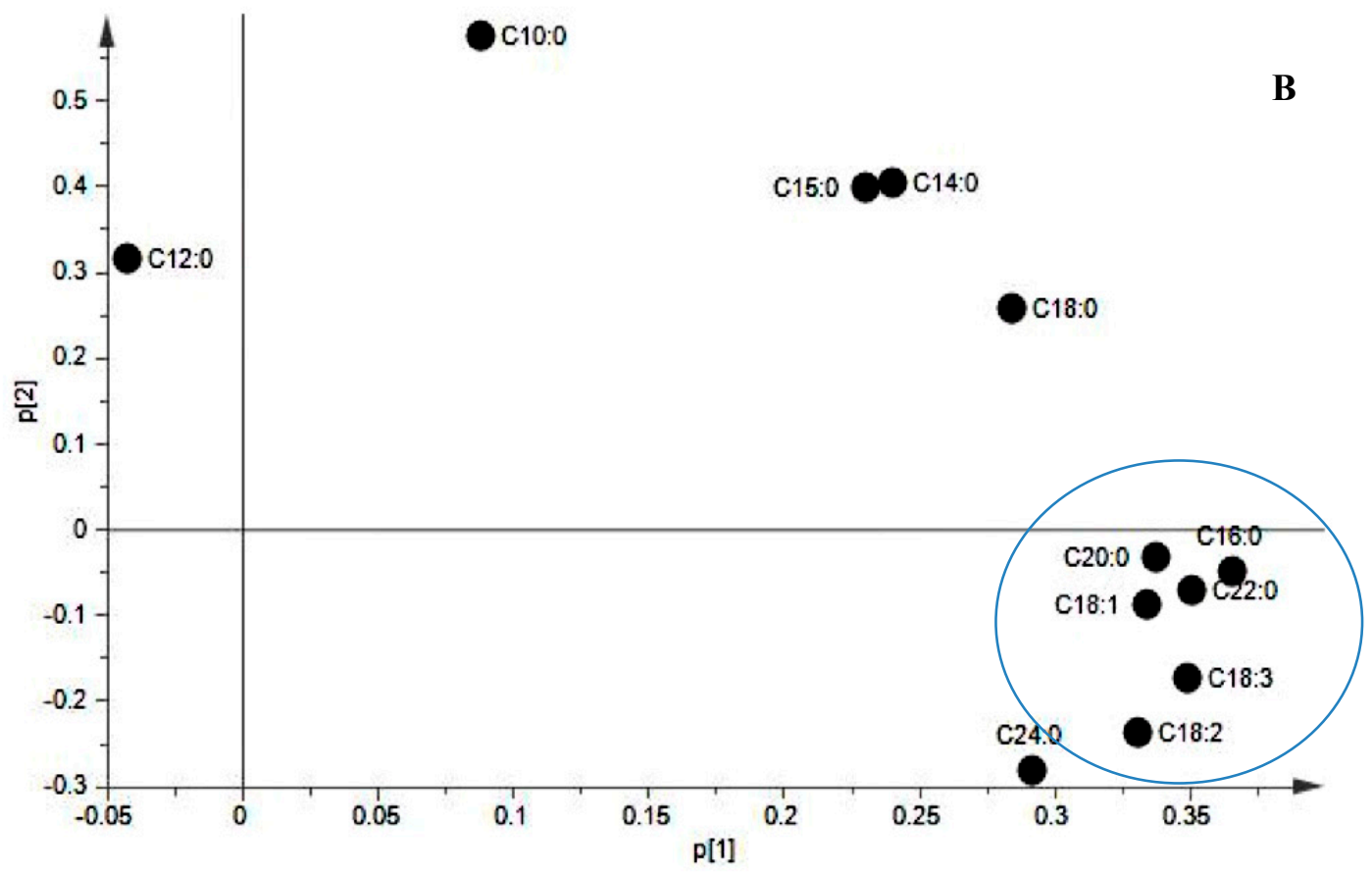


Figure 2. PLS-DA of cell suspension cultures of $C$. roseus treated with JA. (A) Scores plot of FA forming the first class (0-5-30 min after induction). (B) Loadings plot of the first class (0-5-30 min after induction. (C) Scores plot of FA forming the second class (90-360-1440 min after induction). (D) Loadings plot of the second class (90-360-1440 min after induction). Black circles: JA-treated cells; white circles: untreated cells; grey circles: mock $(40 \% \mathrm{EtOH})$.
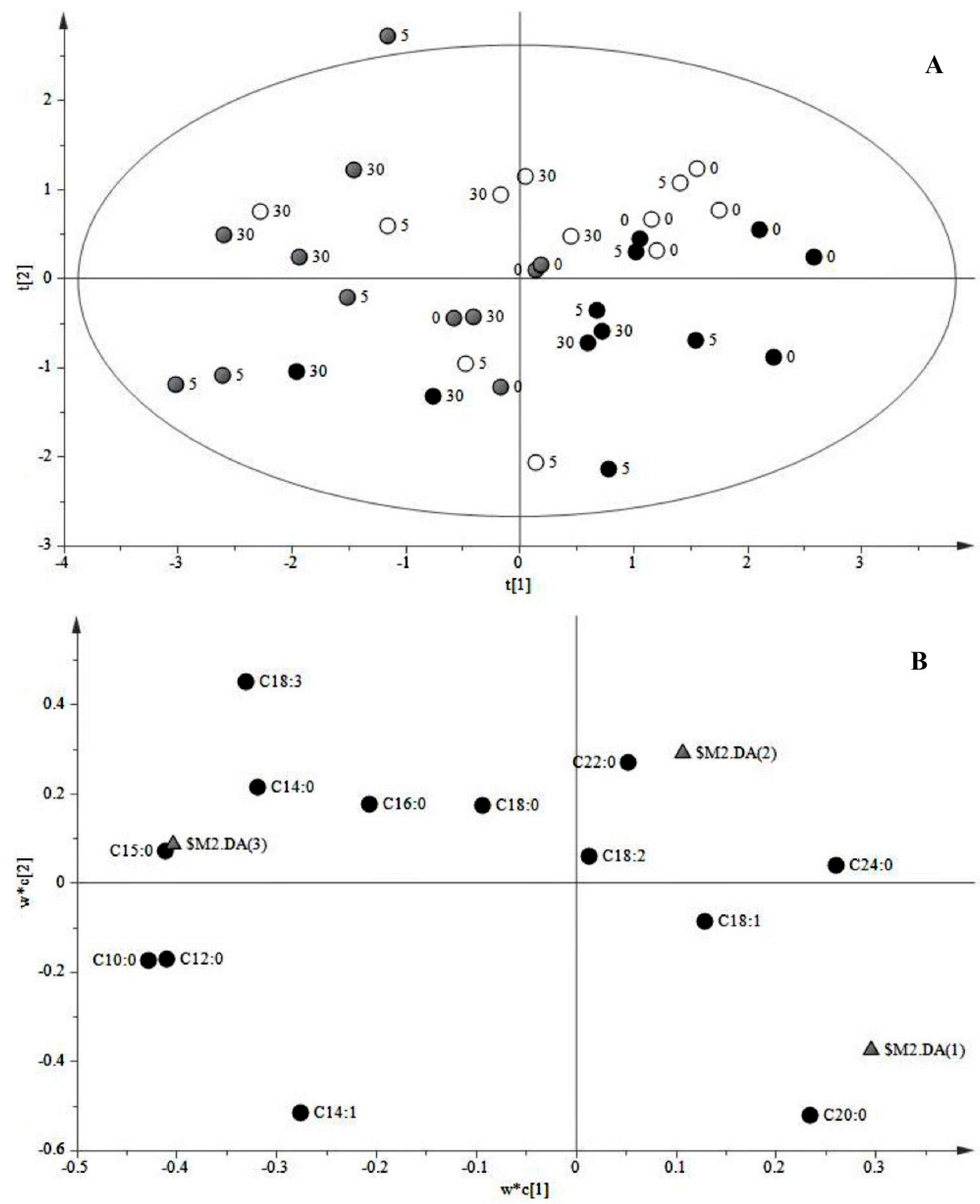
Figure 2. Cont.
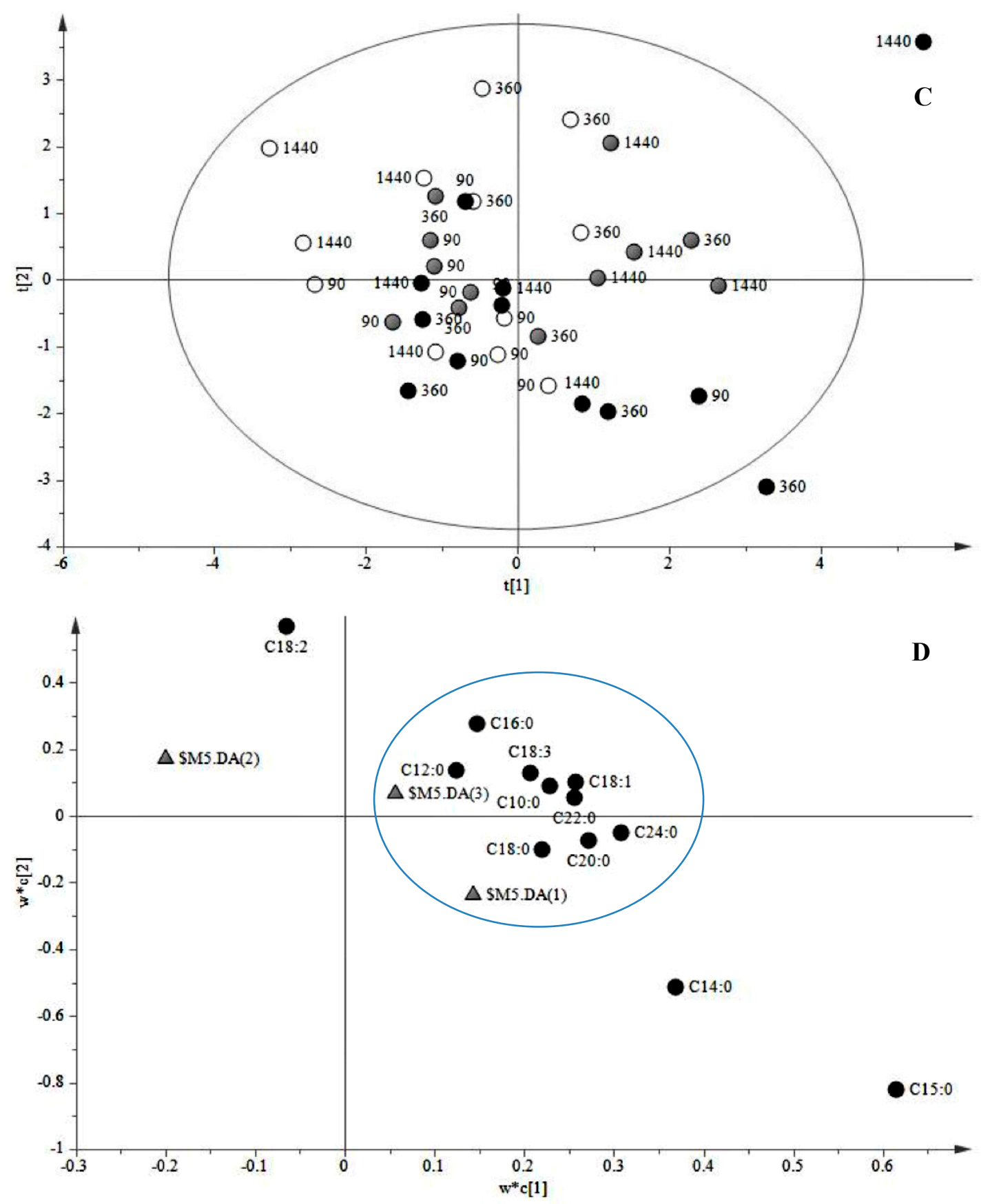

\subsubsection{Effect of JA on TIA Accumulation in Cell Suspensions of C. roseus}

Jasmonic acid was applied to cell suspension cultures of $C$. roseus on the 4th day after subculture. Seven peaks were noticed and distinguished only by their different retention times ( $\alpha$-TIA-1-7). According to their absorbance under ultraviolet (UV) light, three maxima were observed at 225, 300, $325 \mathrm{~nm}$, which is characteristic of alkaloids possessing an $\alpha$-methylene indoline chromophore, constituted by a double bond conjugated with a carbonyl group in the $\alpha$ position of the indoline nitrogen atom, like present in tabersonine. However, the aim of this work was not to identify each trace alkaloid present in our cell system but to get a more general overview of the main TIA accumulated after JA treatment. 
The most significant effects were observed on the accumulation of $\alpha$-TIA-1 and tabersonine after $360 \mathrm{~min}$ of induction whereas catharanthine and serpentine were induced after $1440 \mathrm{~min}$ of elicitation (Figure 3). Levels of catharanthine, $\alpha$-TIA-1 and tabersonine transiently increased after 5 and $360 \mathrm{~min}$ of elicitation, respectively, reaching a maximum after $1440 \mathrm{~min}$ where their accumulation was clearly induced by JA. Previous investigations on cell suspensions of C. roseus treated with $100 \mu \mathrm{M}$ of MeJA, have shown a 300\% increase in alkaloid accumulation like ajmalicine and serpentine [14] and strictosidine [42]. This is in contrast with our observations and previous reports on the same cell line [43] where only serpentine but not strictosidine was induced by JA.

Figure 3. Profiles of the TIA with the most significant variations in cell suspension cultures of $C$. roseus after JA treatment. Values are the mean $\pm \mathrm{SE}$ of one experiment with four biological triplicates. Significant results are marked with stars $(* p<0.05)$.
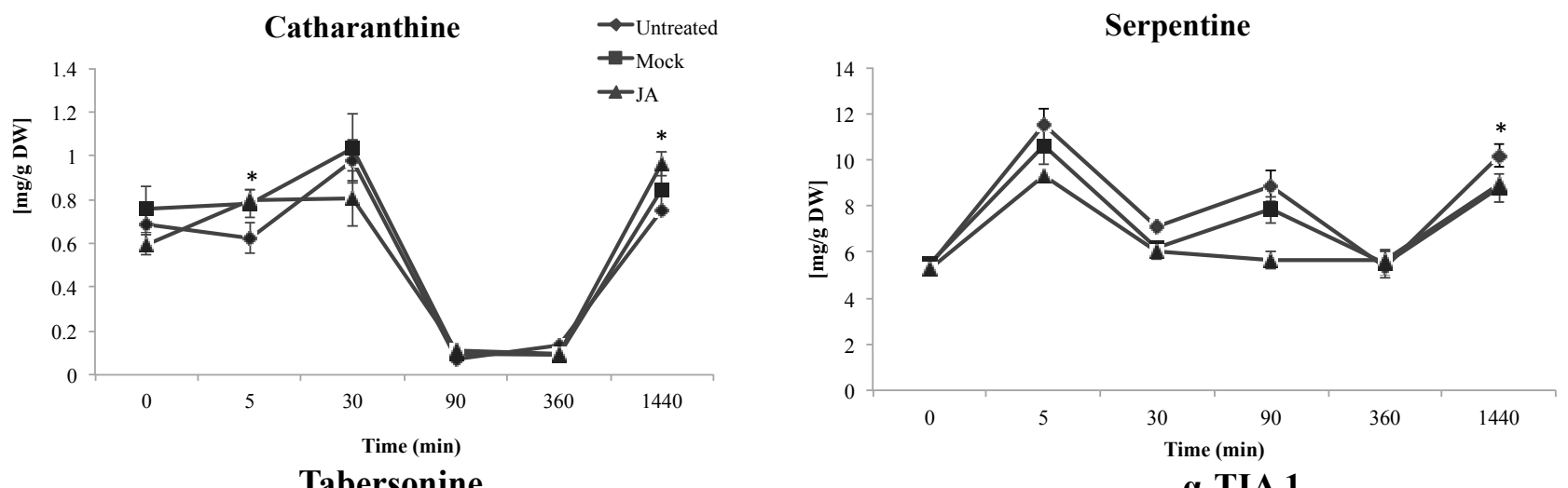

Tabersonine
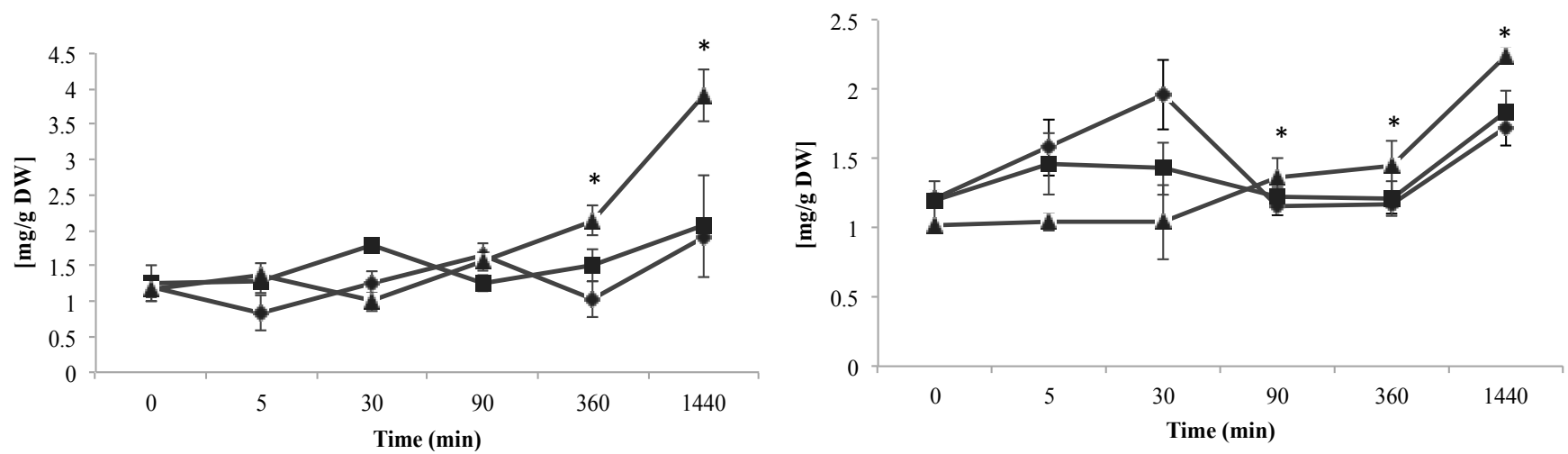

Treatment with JA did not induce the accumulation of vindoline in cell suspension cultures of C. roseus and consequently that of bisindole alkaloids in agreement with previous knowledge [44]. This inability is mainly due to the lack of expression of $D 4 H$ and the transcriptional inactivation of $D A T[45,46]$. This can be explained with the tight regulation in the biosynthesis of vindoline where the enzymes are located in different cellular compartments. The first step in the conversion from tabersonine to vindoline is its hydroxylation [47]. Regardless the fine-tuned regulation in vindoline biosynthesis, some transcripts specific to its biosynthesis have been detected in hairy roots and cell suspension cultures of $C$. roseus [48]. However, exposure of cell cultures of $C$. roseus to light increased the expression of $T 16 \mathrm{H}$ within $22-28 \mathrm{~h}$ of treatment [49] and was also found along with 16OMT to be expressed in cell suspensions cultures in $20 \%$ lower levels than in young leaves of C. roseus [50]. In addition, activities of T16H and $O$-methyltransferase but not that of NMT, D4H and 
DAT are present in cell suspensions of $C$. roseus indicating a degree of separation in the regulation of the first two and last four steps in the conversion of tabersonine to vindoline [50].

\subsubsection{Late Events in the JA Stress Response}

Analysis of PCA scores of FA and TIA allowed the classification of three major time events characterized according to the specific pattern of each compound over time. The three major clusters after JA treatment were 0-5-30 $\mathrm{min}$; 90-360 $\mathrm{min}$ and $1440 \mathrm{~min}$ (Figure 4A). In the first cluster, JA-treated cells were characterized by variations in compounds like C16:0, C18:0, strictosidine, $\alpha$-TIA-1, $\alpha$-TIA-2 and $\alpha$-TIA-5 (Figure 4B). After $90 \mathrm{~min}$ of treatment, changes were associated to variations in C18:3, serpentine, catharanthine, $\alpha$-TIA-1-3 and tabersonine (Figure 4C). The most significant variations were observed after $1440 \mathrm{~min}$ of treatment were JA had a stronger effect on TIA accumulation where alkaloids such as tabersonine, $\alpha$-TIA-1, $\alpha$-TIA-5 catharanthine and vindoline-like were highly induced by JA and another group also induced by JA was conformed by strictosidine, C18:3, C18:2, C18:2, C20:0, C24:0, C22:0 and C16:0 (Figure 4D).

Figure 4. PCA analysis of scores and loadings plots of FA and TIA in cell suspensions of C. roseus after JA treatment. (A) PCA scores plot of FA and TIA profiles allowed the separation of data into three different clusters of events: first cluster (0-5-30 min after JA treatment); second cluster (90-360 min after JA treatment) and third cluster (1440 min after JA treatment). Variances accounted by PC1 and PC2 were $45.3 \%$ and $18.7 \%$, respectively. (B) PCA loadings plot of PC1 vs. PC2 of FA and TIA profiles in the first cluster. (C) PCA loadings plot of the second cluster. (D) PCA loadings plot of the third cluster.

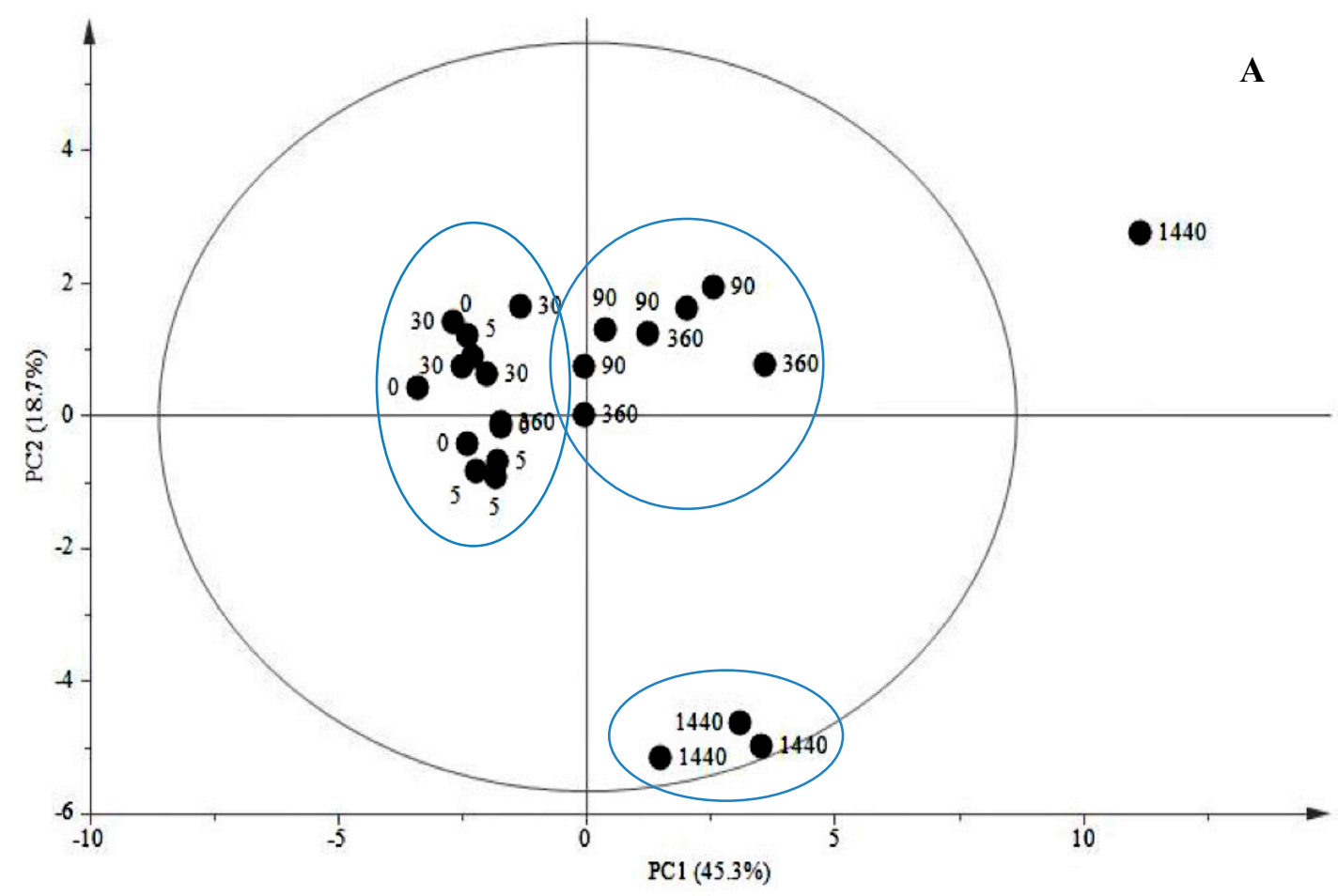


Figure 4. Cont.
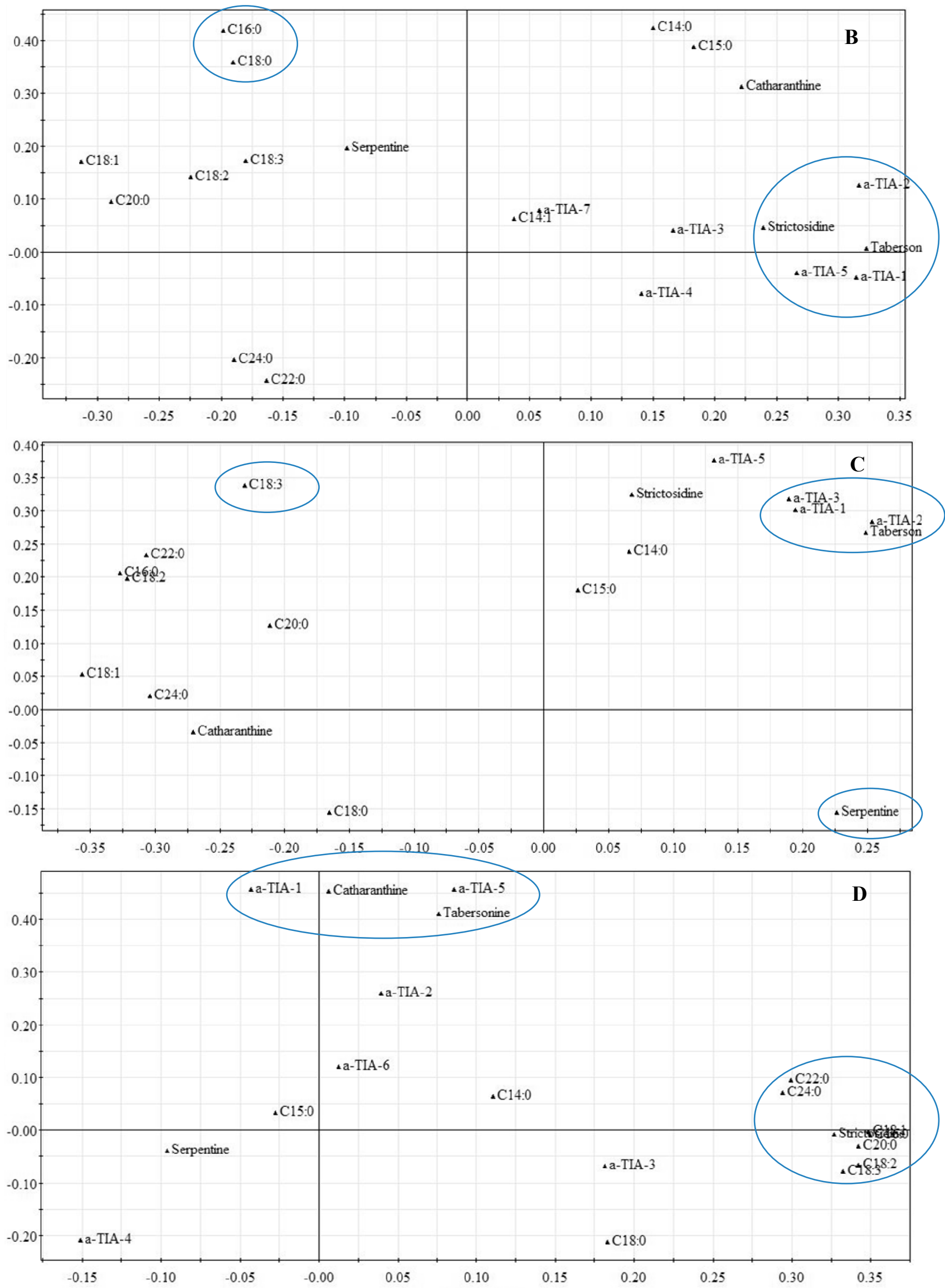
Jasmonic acid exerts well-documented differential responses both in cell systems and in plants in the stress response. Wound-induced experiments in Arabidopsis have shown that the accumulation of JA starts within $120 \mathrm{~s}$ after wounding and spreading the signal to long distance unwounded leaves at an average velocity of $3.4-4.5 \mathrm{~cm} \mathrm{~min}^{-1}$ [19]. Induction of JA accumulation in cell suspension cultures of Rauvolfia canescens takes place within 20-30 min after exposure to a biotic elicitor, reaching a maximum concentration of the free acid after 90 to $240 \mathrm{~min}$ [37,51], which is in complete agreement with our results. These results suggest that de novo biosynthesis of JA starting from the release of C18:3 from thylakoids is very unlikely since lipoxygenase 2 (LOX2) is known to contribute to almost $75 \%$ of JA measured at $24 \mathrm{~h}$ after wounding leaves [52]. Mutants in the LOX pathway such as lox2-1 and $\operatorname{lox} 6 \mathrm{~A}$, were still able to accumulate low levels of JA and JA-Ile in the first 5 min upon wounding but caused $>99 \%$ reduction in the concentrations of 12-oxo-phytodienoic acid (OPDA) and dinor-12oxo-phytodienoic acid (dnOPDA)-containing arabidopsides in wounded leaves [19] and reduction of $J A Z 10$ expression [53] only indicating the redundancy of this family of enzymes but confirming that the fast response is not mediated by them.

Interestingly, when the ability of the precursor of JA i.e., C18:3 to induce TIA accumulation in hairy roots of $C$. roseus was tested and compared to that of JA, it was found that the octadecanoid pathway is not responsible of the production of TIA [54]. Thus, the effects of feeding JA on TIA production to any system are related to pathway induction and not to the relocation of precursors. In contrast, ajmalicine production is highly inducible by MeJA in cell suspension cultures of $C$. roseus where the highest yields $(4.75 \mathrm{mg} / \mathrm{L})$ was observed when cells were treated with $3 \mathrm{mM}$ of $\mathrm{CaCl}_{2}$ and $100 \mu \mathrm{M}$ of MeJA suggesting that cells were dependent on a low intracellular $\mathrm{Ca}^{2+}$ concentration [55], which is in contrast with the previous knowledge that $\mathrm{Ca}^{2+}$ and MeJA induce the production of the transcriptional factors CrBPF-1 (Catharanthus roseus Box P Binding Factor-like protein 1) and ORCAs that regulate the expression of STR [56].

The very fast burst of JA accumulation excludes any transcriptional activation assuming that the endogenous JA is formed from a readily and abundantly precursor and released through a constitutively enzymatic process. A likely scenario includes the liberation and conversion of OPDA and/or dnOPDA both esterified to a monogalactosyldiacylglyceride (MGDG) and/or digalactosyldiacylgliceride (DGDG) into JA, a system so far only found in Arabidopsis [57,58].

The time line of events including primary and secondary metabolites e.g. fatty acids and alkaloids after JA-induction, places their accumulation into a late response since significant increases in C18:3 along with tabersonine, catharanthine, serpentine and $\alpha$-TIA-1 were observed only after 360 min of JA induction with peaking levels after $1440 \mathrm{~min}$. Based on these observations and previous knowledge where $\mathrm{C} 18: 3$ does not induce neither JA nor TIA accumulation in hairy roots of C. roseus, we support the idea that two independent time-events occur after JA induction where in the early response i.e., after 5-30 min of induction, responses include a rapid propagation and intensification of the signal as an "alert-state" to accumulate enough endogenous amounts of JA to enter into a late response i.e. after 6-24 h, where the de novo biosynthesis of precursors like C18:3 and the accumulation of TIA are the result of gene expression mediated through the JA-mediated signaling pathway. 


\section{Experimental Section}

\subsection{Cell Cultures and Elicitation with Jasmonic Acid}

Cell suspension cultures of $C$. roseus cell line CRPP were grown in $250 \mathrm{~mL}$ Erlenmeyer flasks containing $50 \mathrm{~mL}$ of Gamborg B5 [59] medium supplemented with $30 \mathrm{~g} / \mathrm{L}$ sucrose and $1.86 \mathrm{mg} / \mathrm{L}$ 1-naphthaleneacetic acid (NAA) and adjusted to $\mathrm{pH} 5.8$ with $0.1 \mathrm{~N} \mathrm{KOH}$ [43]. Cell cultures were propagated on a rotary shaker $(110 \mathrm{rpm})$ at $25{ }^{\circ} \mathrm{C}$ under continuous light $(500-1500 \mathrm{~lx})$ and were subcultured every three weeks. Four-day-old cell suspension cultures were treated with $101.9 \mu \mathrm{M} / 70 \mathrm{~mL}$ of culture medium of JA (Sigma-Aldrich, St. Louis, MO, USA) or $150 \mu \mathrm{L}$ of $40 \% \mathrm{v} / \mathrm{v}$ EtOH (mock) or nothing (untreated) and were harvested in quadruplicates at 0, 5, 30, 90, 360 and $1440 \mathrm{~min}$ after elicitation. Cells were filtered on Whatman filter paper under partial vacuum and biomass and media samples were immediately frozen in liquid nitrogen and kept at $-80{ }^{\circ} \mathrm{C}$ until further analysis.

\subsection{Chemicals Used for Cell Suspension Cultures}

The chemicals used for macro salts were $\mathrm{CaCl}_{2}$ (min. 99\%), $\mathrm{KH}_{2} \mathrm{PO}_{4}$ (min. 99.5\%), $\mathrm{KNO}_{3}$ (min. 99\%) and $\mathrm{NH}_{4} \mathrm{NO}_{3}$ (min. 99\%) were purchased from Merck (Darmstadt, Germany) and $\mathrm{MgSO}_{4}$ was obtained from OPG Farma (BUVA BV, Uitgeest, The Netherlands). The chemicals used for micro salts were $\mathrm{H}_{3} \mathrm{BO}_{3}, \mathrm{MnSO}_{4} \cdot \mathrm{H}_{2} \mathrm{O}, \mathrm{ZnSO}_{4} \cdot 7 \mathrm{H}_{2} \mathrm{O}, \mathrm{Na}_{2}$ EDTA (Merck) and $\mathrm{FeSO}_{4} \cdot 7 \mathrm{H}_{2} \mathrm{O}$ (Brocades-ACF Groothandel NV, Maarssen, The Netherlands) were dissolved into one solution and $\mathrm{KI}, \mathrm{NaMoO}_{4} \cdot 2 \mathrm{H}_{2} \mathrm{O}$, $\mathrm{CuSO}_{4} \cdot 5 \mathrm{H}_{2} \mathrm{O}$ and $\mathrm{CoCl}_{2} \cdot 6 \mathrm{H}_{2} \mathrm{O}$ (Merck) were dissolved into another solution to avoid insolubility. Thiamine-di-HCl was from Janssen Chimica (Geel, Belgium), pyridoxine-HCl was from SigmaAldrich (St. Louis, MO, USA); nicotinic acid (99.5\%) and glycine (99.7\%) were purchased from Merck, as was NAA, Sucrose (99.7\%) and myo-inositol (99.7\%) were from Duchefa Biochimie (Haarlem, The Netherlands).

\subsection{Chemicals Used for Fatty Acid Determination and Alkaloid Standards}

The mixture of 37 FA methyl esters (37 Component FAME Mix) was obtained from Supelco (Sigma-Aldrich; Bellefonte, PA, USA). All other chemicals and solvents were of analytical grade and purchased from common sources. Water was treated in a Milli-Q water purification system (TGI Pure Water Systems, Brea, CA, USA). Strictosidine and secologanin were provided by Phytoconsult (Leiden, The Netherlands); loganic acid, tabersonine and vindoline were purchased from PhytoLab (Vestenbergsgreuth, Germany); tryptamine was purchased from Sigma-Aldrich Chemical (Milwaukee, WI, USA) tryptophan and ajmalicine were purchased from Sigma-Aldrich; serpentine was purchased from Roth (Karlsruhe, Germany) and catharanthine were kindly gifted by Pierre Fabre (Gaillac, France).

\subsection{Fatty Acid Extraction}

Samples of $10 \mathrm{mg}$ of freeze-dried cells were spiked with $50 \mu \mathrm{g}$ of C17:0 as internal standard and then subjected to hydrolysis with $1 \mathrm{~mL}$ of $1 \mathrm{M}$ of $\mathrm{KOH}$ in $95 \%$ EtOH. The suspension was ultrasonicated for $10 \mathrm{~min}$ followed by heating the closed tube at $80{ }^{\circ} \mathrm{C}$ for $30 \mathrm{~min}$. After cooling at room temperature, $1 \mathrm{~mL}$ of Milli $\mathrm{Q}$ water was added followed by two times extraction with $1 \mathrm{~mL}$ of 
$n$-hexane containing $0.01 \%$ butylated hydroxytoluene (BHT; Sigma-Aldrich), after vigorously vortexing, samples were centrifuged for $10 \mathrm{~min}$ at 3,500 rpm and the upper hexane layer was removed and discarded. The aqueous layer was acidified with $6 \mathrm{M} \mathrm{HCl}$ and extracted twice with $1 \mathrm{~mL} n$-hexane $(0.01 \% \mathrm{BHT})$ and after centrifugation for $10 \mathrm{~min}$ at 3,500 $\mathrm{rpm}$ upper layers were pooled and completely dried under a gentle flow of $\mathrm{N}_{2}$ gas. To the residues $1 \mathrm{~mL}$ of boron trifluoride $\left(\mathrm{BF}_{3}\right.$; SigmaAldrich) in $\mathrm{MeOH}$ was added and the closed tubes were heated for $15 \mathrm{~min}$ at $80{ }^{\circ} \mathrm{C}$ and then cooled down at room temperature and $1 \mathrm{~mL}$ of $n$-hexane $(0.01 \%$ BHT) was added and after centrifugation, the upper layer $(300 \mu \mathrm{L})$ was used in GC-MS analysis.

\subsection{Gas Chromatography-Mass Spectrometry}

FAME analysis was performed on an Agilent 7890A series gas chromatograph equipped with an Agilent 7693 auto sampler and an Agilent 5775C Triple-Axis MSD detector (all from Agilent Technologies Inc., Santa Clara, CA, USA) and separated on a $30 \mathrm{~m} \times 0.25 \mathrm{~mm}$ I.D. $\times 0.25 \mu \mathrm{m}$ film thickness DB-Wax column (J\&W; Agilent Technologies Inc.), with a constant flow of $20 \mathrm{~mL} / \mathrm{min}$ of $\mathrm{He}$ as a carrier gas. The injection port was heated to $250^{\circ} \mathrm{C}$. The injection volume was $1 \mu \mathrm{L}$ with a split ratio of $20: 1$. The oven temperature was $50{ }^{\circ} \mathrm{C}$ for $1 \mathrm{~min}$, then $25{ }^{\circ} \mathrm{C} / \mathrm{min}$ to $200{ }^{\circ} \mathrm{C}$ and then $3{ }^{\circ} \mathrm{C} / \mathrm{min}$ to $250{ }^{\circ} \mathrm{C}$ for $18 \mathrm{~min}$. All mass spectra were acquired in the electron impact (EI) mode for full scan in total ion current (TIC) and selected ion monitoring (SIM) modes. GC-MS was controlled by Enhanced Chemstation software version E.02.00.493 (Agilent Technologies Inc.). Ions selected for quantification are listed in Table 1. The 37 Component FAME Mix was used as a control for possible retention time shifts and mass spectra ion identification.

\subsection{Alkaloid and Precursor Extraction for HPLC}

A modified extraction protocol was followed after [60]. Briefly, freezed-dried samples of $50 \mathrm{mg}$ were extracted twice with $5 \mathrm{~mL}$ of $\mathrm{MeOH}$, vortexed for $1 \mathrm{~min}$, sonicated for $20 \mathrm{~min}$ and then centrifuged for $30 \mathrm{~min}$ at 3,500 rpm. Pooled samples were reduced to dryness under reduced pressure. To the dried extract $500 \mu \mathrm{L}$ of $1 \mathrm{M} \mathrm{H}_{3} \mathrm{PO}_{4}$ was added and the suspension was thoroughly homogenized and then transferred to an Eppendorf tube for centrifugation for $10 \mathrm{~min}$ at 13,000 rpm. Extracts were filtered with a $0.2 \mu \mathrm{m}$ PTFE membrane and then $50 \mu \mathrm{L}$ were analyzed by HPLC.

\subsection{HPLC Analysis}

Chromatographic separations were carried out on a $250 \mathrm{~mm} \times 4.60 \mathrm{~mm}, 5 \mu \mathrm{m}$ Gemini-NX C18 (Phenomenex Inc., Torrance, CA, USA) column and a guard column filled with RSil $\mathrm{C}_{18} \mathrm{HL}$ (Zeochem AG, Uetikon, Switzerland) at room temperature. Elutions were performed at a flow rate of $1.5 \mathrm{~mL} / \mathrm{min}$. Solvents used for TIA were $80 \% 5 \mathrm{mM} \mathrm{Na}_{2} \mathrm{HPO}_{4} \mathrm{pH} 7$ adjusted with $\mathrm{H}_{3} \mathrm{PO}_{4}$; (Solvent A) and 20\% ACN (Solvent B) and for precursors 88\% 0.01 $\mathrm{M} \mathrm{H}_{3} \mathrm{PO}_{4}$ (Solvent A) and 12\% ACN (Solvent B). Gradient analyses modified from [61] were as follows: 80:20 (A:B) to 20:80 in $31 \mathrm{~min}$ for TIA and $88: 12$ (A:B) to $30: 70$ and then to $88: 12$ in $25 \mathrm{~min}$ for precursors, injection volume was $50 \mu \mathrm{L}$. The HPLC system was equipped with an Agilent 1200 Series coupled to an Agilent G1315D photodiode-array detector. It consisted on of a G1310A binary pump, a G1329A autosampler, a 
G1322A degasser and a G1315D photo-diode array detector controlled by ChemStation software (Agilent v. 03.02; all from Agilent Technologies Inc.). Spectroscopic data from all peaks were accumulated in the range of 220-320 nm and chromatograms were recorded at 220, 254, 280, 306 and $320 \mathrm{~nm}$. Detection and quantification was achieved by comparison of their absorbance with that of reference standards.

\subsection{Data Handling}

Differences between treatments, among time points and groups of TIA, regarding contents of each individual TIA in the positive controls were assessed using the Mann-Whitney non-parametric test using R-Project software (v 3.0.0). A $p$-value less than 0.05 was considered statistically significant.

Fatty acids were identified as FAME with the help of the National Institute of Standards and Technology (NIST) library version 2.0f (Agilent Technologies Inc.). Quantification was done by normalizing the peak area of each FA species with that of the internal standard (C17:0). Differences between days and between TIC and SIM, as well as between groups of FA, regarding contents of each individual FA in the positive controls were assessed using the Mann-Whitney non-parametric test using R-Project software (v 3.0.0). A $p$-value less than 0.05 was considered statistically significant. Principal component analysis (PCA) was performed with the SIMCA-P software (v 13.0, Umetrics, Umeå, Sweden). Normalized peak area data was scaled using unit variance (UV). The output from the PCA consisted of a scores plot, which gave an indication of the discrimination of the profile of 13 different FA and a loadings plot, which allowed the identification of those FA with significant influence on the separation of the clustering data.

\section{Conclusions}

Using an MS-based targeted profile, we demonstrate a clear effect of jasmonic acid over time on the FA and TIA accumulation in cell suspensions of $C$. roseus where compounds such as C18:3, C18:2, tabersonine, catharanthine and serpentine had the highest variations. It is very interesting to note that JA applied as an exogenous elicitor induced the accumulation of its own precursor C18:3 but only after 90 min of treatment which cannot explain the fast response seen in the accumulation of JAs. This can only be explained by a larger pool of an intermediate or precursor of JA that is released and immediately activated by a constitutive enzyme system into JA.

\section{Acknowledgments}

We are grateful to Consejo Nacional de Ciencia y Tecnología (CONACYT) for the scholarship given to GDGP.

\section{Author Contributions}

GDGP, NRM, and RV designed the experimental set-up; GDGP performed all the experiments and analyzed the data; GDGP wrote the paper. All authors read and approved the final manuscript. 


\section{Conflicts of Interest}

The authors declare no conflict of interest.

\section{References}

1. Millar, A.A.; Smith, M.A.; Kunst, L. All fatty acids are not equal: Discrimination in plant membrane lipids. Trends Plant. Sci. 2000, 5, 95-101.

2. Kachroo, A.; Kachroo, P. Fatty acid-derived signals in plant defense. Ann. Rev. Phytopathol. 2009, 47, 153-176.

3. Savchenko, T.; Walley, J.W.; Chehab, E.W.; Xiao, Y.; Kaspi, R.; Pye, M.F.; Mohamed, M.E.; Lazarus, C.M.; Bostock, R.M.; Dehesh, K. Arachidonic acid: An evolutionary conserved signaling molecule modulates plant stress signaling networks. Plant Cell 2010, 22, 3191-3205.

4. Feussner, I.; Wasternack, C. The lipoxygenase pathway. Ann. Rev. Plant Biol. 2002, 53, 275-297.

5. MacCarthy, J.J.; Stumpf, P.K. The effect of different temperatures on fatty-acid synthesis and polyunsaturation in cell suspension cultures. Planta 1980, 147, 389-395.

6. Kazemi Shahandashti, S.S.; Maali Amiri, R.; Zeinali, H.; Sanaz Ramezanpour, S.S. Change in membrane fatty acid compositions and cold-induced responses in chickpea. Mol. Biol. Rep. 2013, 40, 893-903.

7. Elkahoui, S.; Smaoui, A.; Zarrouk, M.; Ghir, R.; Limam, F. Salt-induced lipid changes in Catharanthus roseus cultured cell suspensions. Phytochemistry 2004, 65, 1911-1917.

8. Creelman, R.A.; Mullet, J.E. Biosynthesis and action of jasmonates in plants. Ann. Rev. Plant Physiol. Plant. Mol. Biol. 1997, 48, 355-381.

9. Wasternack, C.; Hause, B. Jasmonates and octadecanoids: Signals in plant stress responses and development. Prog. Nucleic Acid. Res. Mol. Biol. 2002, 72, 165-221.

10. Wasternack, C.; Forner, S.; Strnad, M.; Hause, B. Jasmonates in flower and seed development. Biochimie 2013, 95, 79-85.

11. De Domenico, S.; Bonsegna, S.; Horres, R.; Pastor, V.; Taurino, M.; Poltronieri, P.; Imtiaz, M.; Kahl, G.; Flors, V.; Winter, P.; et al. Transcriptomic analysis of oxylipins biosynthesis genes and chemical profiling reveal early induction of jasmonates in chickpea roots under drought stress. Plant. Physiol. Biochem. 2012, 61, 115-122.

12. Collu, G.; Unver, N.; Peltenburg-Looman, A.M.G.; van der Heijden, R.; Verpoorte, R.; Memelink, J. Geraniol 10-hydroxylase, a cytochrome P450 enzyme involved in terpenoid indole alkaloid biosynthesis. FEBS Lett. 2001, 508, 215-220.

13. Lee-Parsons, C.W.T.; Ertürk, S.; Tengtrakool, J. Enhancement of ajmalicine production in Catharanthus roseus cell cultures with methyl jasmonate is dependent on timing and dosage of elicitation. Biotechnol. Lett. 2004, 0, 1595-1599.

14. Li, C.Y.; Leopold, A.L.; Sander, G.W.; Shanks, J.V.; Zhao, L.; Gibson, S.I. The ORCA2 transcription factor plays a key role in regulation of the terpenoid indole alkaloid pathway. BMC Plant. Biol. 2013, 13, 155. 
15. Memelink, J.; Verpoorte, R.; Kijne, J.W. ORCAnization of jasmonate-responsive gene expression in alkaloid metabolism. Trends Plant. Sci. 2001, 6, 212-219.

16. Wei, S. Methyl jasmonic acid induced expression pattern of terpenoid indole alkaloid pathway genes in Catharanthus roseus seedlings. Plant Growth Reg. 2010, 61, 243-251.

17. Moreno, P.R.H.; Poulsen, C.; van der Heijden, R.; Verpoorte, R. Effects of elicitation on different metabolic pathways in Catharanthus roseus (L.) G. Don cell suspension cultures. Enz. Microb. Technol. 1996, 18, 99-107.

18. Vázquez-Flota, F.; Hernández-Domínguez, E.; Miranda-Ham, M.L.; Monforte-González, M. A differential response to chemical elicitors in Catharanthus roseus in vitro cultures. Biotechnol. Lett. 2009, 31, 591-595.

19. Glauser, G.; Dubugnon, L.; Mousavi, S.A.R.; Rudaz, S.; Wolfender, J.L.; Farmer, E.E. Velocity estimates for signal propagation leading to systemic jasmonic acid accumulation in wounded Arabidopsis. J. Biol. Chem. 2009, 284, 34506-34513.

20. Simkin, A.J.; Miettinen, K.; Claudel, P.; Burlat, V.; Guirimand, G.; Courdavault, V.; Papon, N.; Meyer, S.; Godet, S.; St-Pierre, B.; et al. Characterization of the plastidial geraniol synthase from Madagascar periwinkle which initiates the monoterpenoid branch of the alkaloid pathway in internal phloem associated parenchyma. Phytochemistry 2013, 85, 36-43.

21. Toivonen, L.; Laakso, S.; Rosenqvist, H. The effect of temperature on growth, indole alkaloid accumulation and lipid composition of Catharanthus roseus cell suspension cultures. Plant Cell Rep. 1992, 11, 390-394.

22. López, M.G.; Sánchez-Mendoza, I.R.; Ochoa-Alejo, N. Comparative study of volatile components and fatty acid of plants and in vitro cultures of parsley (Petroselinum crispum (Mill) Nym ex Hill. J. Agric. Food Chem. 1999, 47, 3292-3296.

23. MacCarthy, J.J.; Stumpf, P.K. Tissue culture of plants for studies of lipid metabolism. Methods Enzymol. 1981, 72, 754-768.

24. Radwan, S.S.; Mangold, H.K.; Spener, F. Lipids in plant tissue cultures. III. Very long-chain fatty acids in the lipids of callus cultures and suspension cultures. Chem. Phys. Lipids 1974, 13, 103-107.

25. Leathers, R.R.; Scragg, A.H. The effect of different temperatures on the growth, lipid content and fatty acid composition of Theobroma cacao cell suspension cultures. Plant Sci. 1989, 62, 217-227.

26. Pandey-Rai, S.; Rao Mallavarapu, G.; Naqvi, A.A.; Yadav, A.N.; Kumar Rai, S.; Srivastava, S.; Singh. D.; Mishra, R.; Kumar, S. Volatile components of leaves and flowers of periwinkle Catharanthus roseus (L.) Don from New Delhi. Flav. Fragr. J. 2006, 21, 427-430.

27. Brun, G.; Bessière, J.M.; Dijoux-Franca, M.G.; David, B.; Mariotte, A.M. Volatile components of Catharanthus roseus (L.) Don (Apocynaceae). Flav. Fragr. J. 2001, 16, 116-119.

28. Guedes De Pinho, P.; Gonçalves, R.F.; Valentão, P.; Pereira, D.M.; Seabra, R.M.; Andrade, P.B.; Sotomayor, M. Volatile composition of Catharanthus roseus (L.) Don using solid-phase microextraction and gas chromatography/mass spectrometry. J. Pharm. Biomed. Anal. 2009, 49, 674-685.

29. Rezanka, T.; Sigler, K. Odd-numbered very-long-chain fatty acids from the microbial, animal and plant kingdoms. Prog. Lipid Res. 2009, 48, 206-238. 
30. Carriere, F.; Chagvardieff, P.; Gil, G.; Pean, M.; Sigoillot, J.C.; Tapie, P. Fatty acid patterns of neutral lipids from seeds, leaves and cell suspension cultures of Euphorbia characias. Phytochemistry 1992, 31, 2351-2353.

31. Gemmrich, A.R.; Schraudolf, H. Fatty acid composition of lipids from differentiated tissues and cell cultures of Euonymus europaeus. Chem. Phys. Lipids 1980, 26, 259-264.

32. Hansen, C.E.; Rossi, P. Effects of culture condition on accumulation of arachidonic and eicosapentaenoic acids cultured cells of Rhytidiadelphus squarrosus and Eurhynchium striatum. Phytochemistry 1991, 30, 1837-1841.

33. Chiou, S.Y.; Su, W.W.; Su, Y.C. Optimizing production of polyunsaturated fatty acids in Marchantia polymorpha cell suspension culture. J. Biotechnol. 2001, 85, 247-257.

34. Miersch, O.; Neumerkel, J.; Dippe, M.; Stenzel, I.; Wasternack, C. Hydroxylated jasmonates are commonly occurring metabolites of jasmonic acid and contribute to a partial switch-off in jasmonate signaling. New Phytol. 2008, 177, 114-127.

35. Fonseca, S.; Chini, A.; Hamberg, M.; Adie, B.; Porzel, A.; Kramell, R.; Miersch, O.; Wasternack, C.; Solano, R. (+)-7-iso-Jasmonoyl-L-isoleucine is the endogenous bioactive jasmonate. Nat. Chem. Biol. 2009, 5, 344-350.

36. Conconi, A.; Miquel, M.; Browse, J.A.; Ryan, C.A. Intracellular levels of free linolenic and linoleic acids increase in tomato leaves in response to wounding. Plant. Physiol. 1996, 111, 797-803.

37. Mueller, M.J.; Brodschelm, W.; Spannagl, E.; Zenk, M.H. Signaling in the elicitation process is mediated through the octadecanoid pathway leading to jasmonic acid. Proc. Natl. Acad. Sci. USA 1993, 90, 7490-7494.

38. Dewir, Y.H.; Chakrabarty, D.; Wu, C.H.; Hahn, E.J.; Jeon, W.K.; Paek, K.Y. Influences of polyunsaturated fatty acids (PUFAs) on growth and secondary metabolite accumulation in Panax ginseng C.A. Meyer adventitious roots cultures in air-lift bioreactors. South Afr. J. Bot. 2010, 76, 354-358.

39. Wu, C.H.; Popova, E.V.; Hahn, E.J.; Paek, K.Y. Linolenic and $\alpha$-linolenic fatty acids affect biomass and secondary metabolite production and nutritive properties of Panax. ginseng adventitious roots cultured in bioreactors. Biochem. Eng. J. 2009, 47, 109-115.

40. Gundlach, H.; Zenk, M.H. Biological activity and biosynthesis of pentacyclic oxylipins: The linoleic acid pathway. Phytochemistry 1998, 47, 527-537.

41. Véronési, C.; Pouénat, M.L.; Rickauer, M.; Esquerrê-Tugayé, M.T. Regulation of tobacco lipoxygenase by methyl jasmonate and fatty acids. Comp. Rend Acad. Sci. Series III Sci. Vie 1999, 322, 491-497.

42. El-Sayed, M.; Verpoorte, R. Effect of phytohormones on growth and alkaloid accumulation by a Catharanthus roseus cell suspension cultures fed with alkaloid precursors tryptamine and loganin. Plant Cell Tis. Org. Cult. 2002, 68, 265-270.

43. Saiman, M.Z.; Mustafa, R.N.; Pomahacova, B.; Verbenne, M.; Verpoorte, R.; Choi, Y.H.; Schulte, A.E. Analysis of metabolites in the terpenoid pathway of Catharanthus roseus cell suspensions. Plant Cell Tissue Organ. Cult. 2014, 117, 225-239.

44. Endo, T.; Goodbody, A.; Misawa, M. Alkaloid production in root and shoot cultures of Catharanthus roseus. Planta Med. 1987, 53, 479-482. 
45. Vázquez-Flota, F.; de Luca, V.; Carrillo-Pech, M.; Canto-Flick, A.; Miranda-Ham, M.L. Vindoline biosynthesis is transcriptionally blocked in Catharanthus roseus cell suspension cultures. Mol. Biotechnol. 2002, 22, 1-8.

46. Shukla, A.K.; Shasany, A.K.; Verma, R.K.; Gupta, M.M.; Mathur, A.K.; Khanuja, S.P.S. Influence of cellular differentiation and elicitation on intermediate and late steps of terpenoid indole alkaloid biosynthesis in Catharanthus roseus. Protoplasma 2010, 242, 35-47.

47. Besseau, S.; Kellner, F.; Lanoue, A.; Thamm, A.M.K.; Salim, V.; Schneider, B.; Geu-Flores, F.; Höfer, R.; Guirimand, G.; Guihur, A.; et al. A pair of tabersonine 16-hydroxylases initiates the synthesis of vindoline in an organ-dependent manner in Catharanthus roseus. Plant Physiol. 2013, 163, 1792-1803.

48. Verpoorte, R.; van der Heijden, R.; Moreno, P.R.H. Biosynthesis of terpenoid indole alkaloids in Catharanthus roseus cells. In The Alkaloids; Cordell, G.A., Ed.; Academic Press: Waltham, MA, USA, 1997; Volume 49, pp. 221-299.

49. Schröder, G.; Unterbusch, E.; Kaltenbach, M.; Schmidt, J.; Strack, D.; de Luca, V.; Schröder, J. Light-induced cytochrome P450-dependent enzyme in indole alkaloid biosynthesis: Tabersonine 16-hydroxylase. FEBS Lett. 1999, 458, 97-102.

50. St-Pierre, B.; de Luca, V. A cytochrome P-450 monooxygenase catalyzes the first step in the conversion of tabersonine to vindoline in Catharanthus roseus. Plant Physiol. 1995, 109, 131-139.

51. Gundlach, H.; Müeller, M.J.; Kutchan, T.M.; Zenk, M.H. Jasmonic acid is a signal transducer in elicitor-induced plant cell cultures. Proc. Natl. Acad. Sci. USA 1992, 89, 2389-2393.

52. Bell, E.; Creelman, R.A.; Mullet, J.E. A chloroplast lipoxygenase is required for wound-induced jasmonic acid accumulation in Arabidopsis. Proc. Natl. Acad. Sci. USA 1995, 92, 8675-8679.

53. Chauvin, A.; Caldelari, D.; Wolfender, J.L.; Farmer, E.E. Four lipoxygenases contribute to rapid jasmonate synthesis in wounded Arabidopsis thaliana leaves: A role for lipoxygenase 6 in response to long-distance wound signals. New Phytol. 2013, 197, 566-575.

54. Peebles, C.A.M.; Shanks, J.V.; San, K.Y. The role of the octadecanoid pathway in the production of terpenoid indole alkaloids in Catharanthus roseus hairy roots under normal and UV-B stress conditions. Biotechnol. Bioeng. 2009, 103, 1248-1254.

55. Lee-Parsons, C.W.T.; Ertürk, S. Ajmalicine production in methyl jasmonate-induced Catharanthus roseus cell cultures depends on $\mathrm{Ca}^{2+}$ level. Plant Cell Rep. 2005, 24, 677-682.

56. Van der Fits, L.; Zhang, H.; Menke, F.L.H.; Deneka, M.; Memelink, J. A Catharanthus roseus BPF-1 homologue interacts with an elicitor-responsive region of the secondary metabolite biosynthetic gene Str. and is induced by elicitor via a JA-dependent signal transduction pathway. Plant Mol. Biol. 2000, 44, 675-685.

57. Hisamatsu, Y.; Goto, N.; Hasegawa, K.; Shigemori, H. Arabidopsides A and B, tow new oxylipins from Arabidopsis thaliana. Tehtrah. Lett. 2003, 44, 5553-5556.

58. Hisamatsu, Y.; Goto, N.; Sekiguchi, M.; Hasegawa, K.; Shigemori, H. Oxylipins arabidopsides C and D from Arabidopsis thaliana. J. Nat. Prod. 2005, 68, 600-603.

59. Gamborg, O.L.; Miller, R.A.; Ojima, K. Nutrient requirements of suspension cultures of soybean root cells. Exp. Cell. Res. 1968, 50, 151-158. 
60. Moreno, P.R.H.; van de Heijden, R.; Verpoorte, R. Effect of terpenoid precursor feeding and elicitation on formation of indole alkaloids in cell suspension cultures or Catharanthus roseus. Plant Cell Rep. 1993, 12, 702-705.

61. Tikhomiroff, C.; Jolicoeur, M. Screening of Catharanthus roseus secondary metabolites by high-performance liquid chromatography. J. Chromatogr. A 2002, 955, 87-93.

Sample Availability: Not available.

(C) 2014 by the authors; licensee MDPI, Basel, Switzerland. This article is an open access article distributed under the terms and conditions of the Creative Commons Attribution license (http://creativecommons.org/licenses/by/3.0/). 